\title{
Barium, zinc and strontium yellows in late 19th-early 20th century oil paintings
}

Vanessa Otero $^{1^{*}} \mathbb{0}$, Marta F. Campos ${ }^{1}$, Joana V. Pinto ${ }^{2}$, Márcia Vilarigues ${ }^{1}$, Leslie Carlyle ${ }^{1}$ and Maria João Melo ${ }^{1}$

\begin{abstract}
This work focuses on the study of the 19th century yellow chromate pigments based on barium $\left(\mathrm{BaCrO}_{4}\right)$, zinc $\left(4 \mathrm{ZnCrO}_{4} \cdot \mathrm{K}_{2} \mathrm{O} \cdot 3 \mathrm{H}_{2} \mathrm{O}\right)$ and strontium $\left(\mathrm{SrCrO}_{4}\right)$. These pigments, which are reported to shift in hue and darken, have been found in 19th century artworks. A better understanding of their historic manufacture will contribute to the visual/chemical interpretation of change in these colours. Research was carried out on the Winsor \& Newton (W\&N) 19th century archive database providing a unique insight into their manufacturing processes. One hundred and three production records were found, $69 \%$ for barium, $25 \%$ for zinc and $6 \%$ for strontium chromates, mainly under the names Lemon, Citron and Strontian Yellow, respectively. Analysis of the records shows that each pigment is characterised by only one synthetic pathway. The low number of records found for the production of strontium chromate suggests W\&N was not selling this pigment formulation on a large scale. Furthermore, contrary to what the authors have discovered for W\&N chrome yellow pigments, extenders were not added to these pigment formulations, most probably due to their lower tinting strength (TS). The latter was calculated in comparison to pure chrome yellow $\left(\mathrm{PbCrO}_{4}, 100 \% \mathrm{TS}\right)$ resulting in 92\% for barium, 65\% for zinc potassium and 78\% for strontium chromate pigments. This indicates that W\&N was probably using extenders primarily to adjust pigment properties and not necessarily as a means to reduce their costs. Pigment reconstructions following the main methods of synthesis were characterised by complementary analytical techniques: Fibre optic reflectance spectroscopy, X-ray diffraction, micro-Raman and micro-Fourier transform infrared spectroscopies. These pigments can be clearly distinguished on the basis of their infrared $\mathrm{CrO}_{4}{ }^{2-}$ asymmetric stretching fingerprint profile (between 1000 and $700 \mathrm{~cm}^{-1}$ ) and of their Raman $\mathrm{CrO}_{4}{ }^{2-}$ stretching bands $\left(850-950 \mathrm{~cm}^{-1}\right)$. This enabled their identification in historic paint samples: a tube of late 19th century W\&N Lemon Yellow oil paint and micro-samples from paintings by three Portuguese painters, António Silva Porto (1850-1893), João Marques de Oliveira (1853-1927) and Amadeo de Souza-Cardoso (1887-1918). The good correlation found between the reconstructions and historic samples validates their use as reference materials for future photochemical studies.
\end{abstract}

Keywords: Barium yellow, Zinc yellow, Strontium yellow, Reconstructions, Winsor \& Newton archive, 19th century paintings, $\mu$-Raman, $\mu$-FTIR, FORS, XRD

\section{Introduction}

Vauquelin's discovery of chromium in 1797 and of the differently coloured compounds derived from it, led to the development of a range of new yellow pigments, the most popular being chrome yellow (lead chromate) [1]. In addition, three yellow chromates based on barium,

\footnotetext{
*Correspondence: van_otero@campus.fct.unl.pt

1 Department of Conservation and Restoration and LAQV-REQUIMTE,

Faculty of Sciences and Technology, Universidade NOVA de Lisboa,

2829-516 Monte da Caparica, Portugal

Full list of author information is available at the end of the article
}

zinc and strontium were introduced. While not as popular with artists, these three new yellows were nevertheless adopted throughout the 19th century [2-6]. Burnstock et al. identified these compounds in 19th to 20th century pigments and paints using X-ray diffraction (XRD) and scanning electron microscopy (SEM) with elemental analysis [6]. They are still in use today, especially as anticorrosive pigments [7]. Table 1 includes their common and chemical names, chemical formula, colour index (C.I.) numbers and other characteristics. 
Table 1 Chrome, barium, zinc and strontium yellow pigments: common and chemical names, chemical formula, colour index number (C.I.), refractive index, solubility product constants $\left(K_{\text {sp }}\right.$ at $\left.25^{\circ} \mathrm{C}\right)$, crystal structure and space group [8-11]

\begin{tabular}{lllll}
\hline Common names & Chrome yellow & $\begin{array}{l}\text { Barium yellow } \\
\text { Lemon yellow }\end{array}$ & $\begin{array}{l}\text { Zinc yellow } \\
\text { Citron yellow }\end{array}$ & $\begin{array}{l}\text { Strontium yellow } \\
\text { Strontian yellow }\end{array}$ \\
\hline Chemical name & Lead chromate & Barium chromate & Zinc potassium chromate hydrate & Strontium chromate \\
Chemical formula & $\mathrm{PbCrO}_{4}$ & $\mathrm{BaCrO}_{4}$ & $4 \mathrm{ZnCrO}_{4} \cdot \mathrm{K}_{2} \mathrm{O} \cdot 3 \mathrm{H}_{2} \mathrm{O}$ & $\mathrm{SrCrO}_{4}$ \\
C.I. pigment yellow & $34: 77600$ & $31: 77103$ & $36: 77955$ & $32: 77839$ \\
Refractive index & $2.3-2.65$ & $1.94-1.98$ & $1.84-1.9$ & $1.92-2.01$ \\
$K_{\text {sp }}$ & $1.8 \times 10^{-14}$ & $1.17 \times 10^{-10}$ & $3.3 \times 10^{-11 \mathrm{~b}}$ & $3.5 \times 10^{-5}$ \\
Crystal structure & Monoclinic & Orthorhombic & Monoclinic & Monoclinic \\
Space group & $\mathrm{P} 2_{1} / \mathrm{n}$ & $\mathrm{P} 2_{1} / \mathrm{n}$ & $\mathrm{P}_{1} / \mathrm{n}$ \\
\hline
\end{tabular}

a The designation "lemon yellow" was also used for zinc and strontium chromates [5] but herein it will only refer to barium chromate

b The solubility product constant of zinc yellow is not tabulated. It was calculated using the data from Simonsen et al. [12]

Barium chromate $\left(\mathrm{BaCrO}_{4}\right)$, first synthesised and analysed by Vauquelin, resulted from adding a solution of barium nitrate to a chromate or dichromate (e.g. sodium or potassium) solution [1]. Barium chloride may also be used as an alternative source of barium $[2,13]$. Throughout the 19th century, barium chromate was known under several different names including: barium yellow, lemon yellow, ultramarine yellow, baryta yellow and Steinbühl yellow $[2,14]$.

Zinc chromate with the approximate composition of $4 \mathrm{ZnCrO} \cdot \cdot \mathrm{K}_{2} \mathrm{O} \cdot 3 \mathrm{H}_{2} \mathrm{O}$ also appeared in the beginning of the 19th century, and the origin of its discovery is unclear [1]. Recently, Simonsen et al. have determined its structure as $\mathrm{KZn}_{2}\left(\mathrm{CrO}_{4}\right)_{2} \mathrm{H}_{2} \mathrm{O}(\mathrm{OH})$ by single-crystal X-ray crystallography [12]. This pigment is formed by precipitation when a solution of a zinc salt is added to a chromate solution (e.g. of sodium or potassium), in the presence of potassium ions [2]. During the 19th century, the most common names for zinc chromate were zinc yellow and citron yellow but it was also labeled as ultramarine yellow, yellow button of gold and permanent yellow [2, 5, 14].

It is also uncertain who synthesised strontium chromate $\left(\mathrm{SrCrO}_{4}\right)$ for the first time [2, 14]. Presently it is obtained when a solution of strontium chloride is added to a sodium dichromate solution [7]. During the 19th century onwards, it appears variously as: strontian yellow, strontaine yellow, lemon yellow and ultramarine yellow (the last two names could also refer to barium chromate) $[2,5,14]$.

Of the three yellow chromate pigments, barium chromate is considered the most lightfast, nevertheless, it is reported to turn green after long exposure to light [1]. This agrees with the reactivity model suggested by Monico and Tan et al., that relates the tendency to degrade with the solubility of the chromate pigments, see Table $1[15,16]$. Darkening of zinc chromate $\left(4 \mathrm{ZnCrO}_{4} \cdot \mathrm{K}_{2} \mathrm{O} \cdot 3 \mathrm{H}_{2} \mathrm{O}\right)$ has been observed in Georges Seurat's paintings including A Sunday on La Grande Jatte-1884 [4, 17-19]. Casadio et al. studied the darkening of oil paints prepared with a modern zinc yellow (DuPont, Y-539-D; PS-83109) and cold pressed linseed oil (W\&N), and subjected to artificial aging under combined environmental conditions: light/ dark, air humidity (50 and $90 \% \mathrm{RH}$ ) and acidic gases $\left(\mathrm{SO}_{2}\right.$ and $\left.\mathrm{CO}_{2}\right)$. Colour changes were observed in all aging experiments, but the highest degree of darkening occurred in the presence of light, $\mathrm{SO}_{2}$ and $90 \% \mathrm{RH}$. By means of Electron energy loss spectroscopy (EELS) and $\mathrm{X}$-ray absorption near-edge spectroscopy (XANES), they determined that the darkening is related to the reduction of the original $\mathrm{Cr}(\mathrm{VI})$ in zinc yellow pigment to $\mathrm{Cr}(\mathrm{III})$ species such as the green chromium oxide $\left(\mathrm{Cr}_{2} \mathrm{O}_{3}\right)$. Orange $\mathrm{Cr}(\mathrm{VI})$ dichromate species were also detected in the samples aged under light, $\mathrm{SO}_{2}$ and $50 \%$ RH [17-19].

\section{The investigative methodology}

The present study was prompted by the identification of barium and zinc chromate in oil paintings by the Portuguese Naturalists António Silva Porto (1850-1893) and João Marques de Oliveira (1853-1927), Fig. 1 (see also Additional file 1: Figure S1) [20]. Strontium chromate was also found in oil paintings by Silva Porto [20] and by the Portuguese Modernist Amadeo de Souza-Cardoso (1887-1918), Fig. 2 [21]. The study of the materials and techniques of these painters was carried out in the framework of the interdisciplinary project 'Crossing Borders: History, materials and techniques of Portuguese painters from 1850 to 1918 (Romanticism, Naturalism and Modernism)'. Previously, Correia et al. had identified barium and strontium chromate using $\mu$-Raman in oil paintings by the Portuguese Naturalist Henrique Pousão (18591884) [22]. 

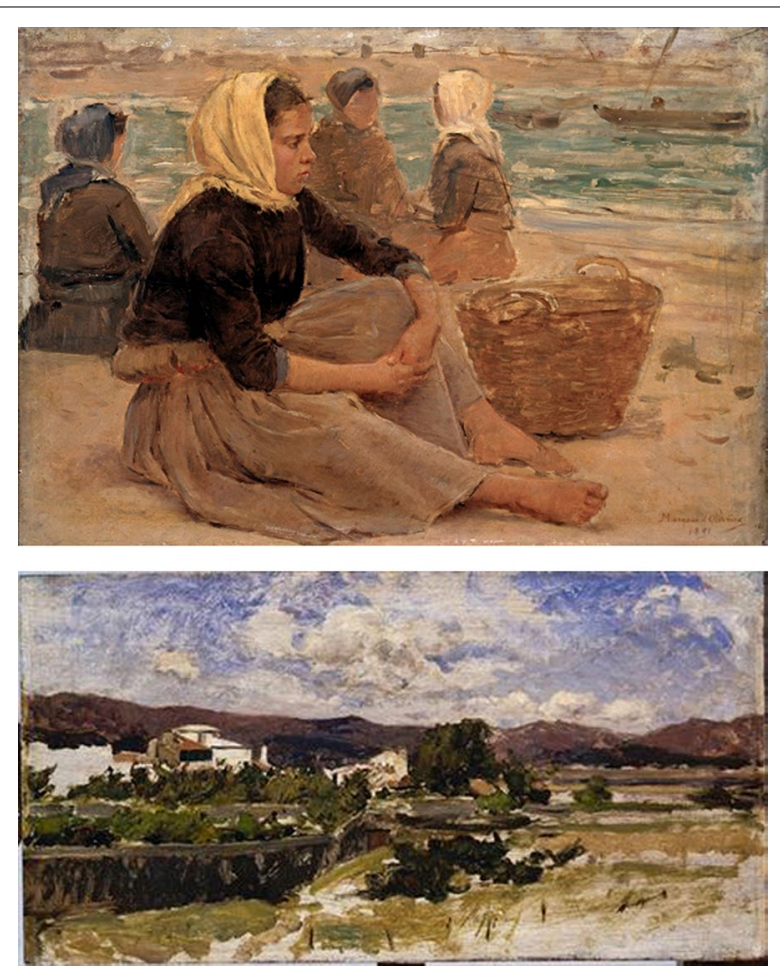

Fig. 1 Top: À espera dos barcos (estudo) ['Waiting for the boats (study)'] (1891, $25.5 \times 37.5 \mathrm{~cm}$ ) by Marques de Oliveira, National Museum of Contemporary Art-Museu do Chiado (Museu Nacional de Arte Contemporânea do Chiado), Lisbon. Bottom: Paisagem (Torres Vedras) ['Landscape (Torres Vedras)'] (1881-89, $25.8 \times 48.8 \mathrm{~cm}$ ) by Silva Porto, House-Museum Dr. Anastácio Gonçalves (Casa-Museu Dr. Anastácio Gonçalves), Lisbon

In previous publications, the authors have demonstrated the unique value of the Winsor \& Newton (W\&N) 19th century archive database for providing efficient access to records covering the commercial preparation of 19th century artists' materials [23, 24]. Following the methodology established for the study of W\&N's lead chromate yellow pigments [25], this paper investigates the preparation and chemistry of barium, zinc and strontium chromate pigments. During the 19th century, these pigments were sold by W\&N under the trade names Lemon Yellow (barium chromate), Citron Yellow (zinc potassium chromate) and Strontian Yellow (strontium chromate). According to Carlyle, who studied the powders and oil colours available in the W\&N 19th century catalogues, the first was listed in c.1835 while the latter two appeared for the first time in a catalogue from c.1861. Strontian Yellow last appeared in a catalogue from c.1896 [5].

The methodology of this study involved analysing W\&N's pigment production records to establish the main method of synthesis for each pigment, then reconstructing the pigment to serve as a reference sample. The chemistry and characteristics of the reconstructed pigments were investigated using Fibre optic reflectance spectroscopy (FORS), X-ray diffraction (XRD), microRaman ( $\mu$-Raman) and micro-Fourier transform infrared ( $\mu$-FTIR) spectroscopies. Their composition was compared with samples from a late 19th century W\&N "Lemon Yellow" tube of oil paint and late 19th-and early 20th century Portuguese oil paintings, Figs. 1 and 2.

\section{Results and discussion}

\section{Research using the W\&N 19th century archive database}

Research into W\&N's pigment manufacture using the W\&N 19th century archive database resulted in the identification of 103 production records for yellow chromate pigments based on barium, zinc and strontium (compared with 183 productions records found for yellow lead chromate pigments [25]). There are 71 production records for Lemon Yellow (also under the names Chromate Barytes and Permanent Primrose) corresponding to barium chromate, 26 for Citron Yellow (or Chromate of Zinc) which correspond to zinc potassium chromate, and six for Strontian Yellow (or Chromate Strontia) resulting in strontium chromate. Contrary to the wide range of names used for lead chromate pigments in W\&N's production records [25], further variations on naming for these three pigments were not found in the W\&N archive.

The pigment composition in the production records is in agreement with W\&N's declaration of their pigment compositions from $1892^{1}$ where Lemon Yellow is described as chromate of barium and Citron Yellow is given as chromate of zinc. On the other hand, it is notable that Strontian Yellow is not included in W\&N's 1892 declaration. Its absence is likely because it was considered too fugitive for $\mathrm{W} \& \mathrm{~N}$ and may explain why there are so few records for the production of strontium chromate. Evidence for this assumption appears in a book belonging to Arthur Henry Newton (son of W\&N's founder Henry Charles Newton). Associated with a recipe for a physical mixture of Lemon Yellow (barium chromate) with Citron Yellow (zinc potassium chromate) which appears under the name: "Strontian Yellow: No. 2 for Oil", dated 23/11/1859, is a note: "In Father's opinion this is a much safer color to use in oil than Chromate of Strontia" (W\&N Database Unique Recipe Code: P2P264AL07). In W\&N's 1892 declaration, this physical mixture appears under the name Primrose Yellow and is described as "similar in colour to the old 'Strontian Yellow' (Chromate of Strontium) but keeps its colour better". Despite this

\footnotetext{
${ }^{1}$ In 1892, W\&N was the first artists' colourmen to publish a document on the chemical composition and permanence of their colours (analysed and studied by them), which was included in their catalogues from this time forward.
} 


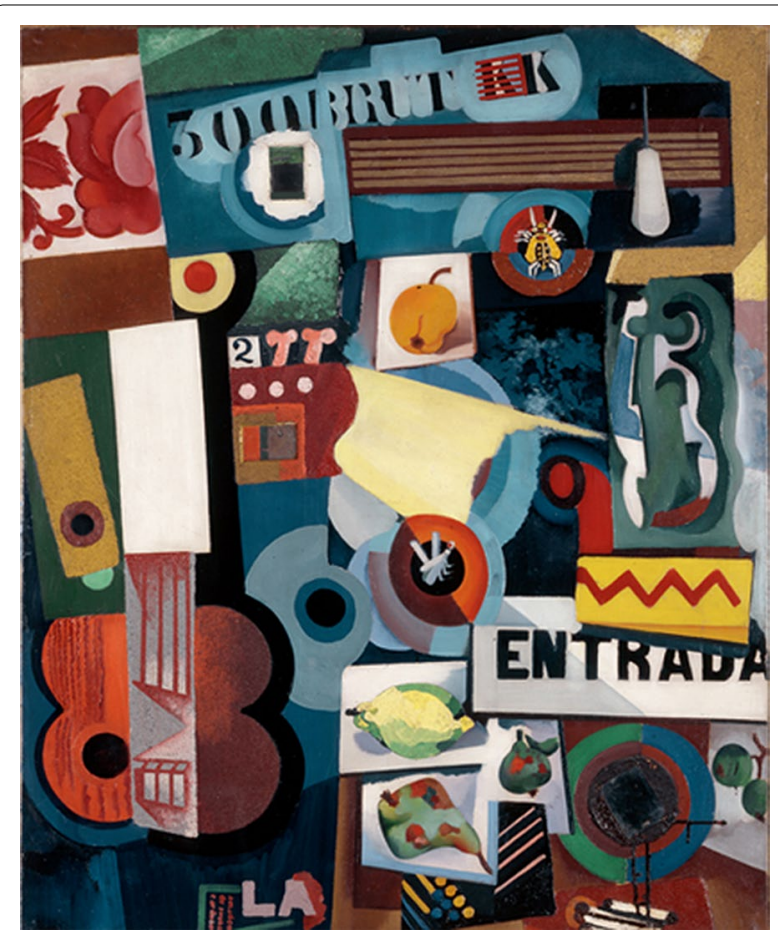

Fig. 2 Untitled (Entrada) ('Entrance') $(c .1917,93.5 \times 75.5 \mathrm{~cm}$ ) by Amadeo de Souza-Cardoso, Modern Art Centre of the Calouste Gulbenkian Foundation, Lisbon observation both Citron Yellow and Primrose Yellow were nevertheless designated fugitive in oil in W\&N's 1892 declaration, with only Lemon Yellow considered permanent in oil. Interestingly, this is contrary to the position of Jehan-Georges Vibert, a 19th century authority on painting materials and supplier as well as consultant to the 19th century artists' colourman Lefranc \& Co. $[3,5]$. He placed strontium chromate in a list of permanent or "good" pigments, together with zinc chromate whereas barium chromate belonged to the list of "bad" pigments (he declared lead chromate pigments "more or less bad") [26].

W\&N manufacturing processes for barium, zinc and strontium chromate pigments

As found to be the case for W\&N's 19th century manufacture of lead chromate pigments [25], once all the production records were analysed for barium, zinc and strontium chromates, it was evident that the company was using a limited number of methods for synthesis. Their main synthetic pathways are described in Table 2 . The full range of process variations is presented in the Additional file 2 along with the number of production records and the date range for each manufacturing process (Additional file 2: Tables S1-S4, Figures S2-S4).

Table 2 W\&N's lemon, citron and strontian yellows: key ingredients, main synthetic pathways and final pigment formulation, compared with one of the main pathways to produce W\&N Chrome Yellow (Lemon Chrome) [25]

\begin{tabular}{|c|c|c|c|c|c|c|c|c|}
\hline \multicolumn{9}{|c|}{ Key ingredients } \\
\hline \multicolumn{2}{|c|}{ Chromate source } & Buffer & \multirow[t]{2}{*}{$\begin{array}{l}\text { Barium } \\
\text { source }\end{array}$} & \multirow[t]{2}{*}{$\begin{array}{l}\text { Zinc } \\
\text { source }\end{array}$} & \multirow[t]{2}{*}{$\begin{array}{l}\text { Strontium } \\
\text { source }\end{array}$} & $\begin{array}{l}\text { Sulphate } \\
\text { source }\end{array}$ & \multirow[t]{2}{*}{$\begin{array}{l}\text { Lead } \\
\text { source }\end{array}$} & \multirow[t]{2}{*}{ Filler } \\
\hline a & b & & & & & & & \\
\hline $\begin{array}{l}\mathrm{K}_{2} \mathrm{Cr}_{2} \mathrm{O}_{7} \\
+\mathrm{Na}_{2} \mathrm{CO}_{3}\end{array}$ & $\mathrm{~K}_{2} \mathrm{Cr}_{2} \mathrm{O}_{7}$ & ${ }_{2} \mathrm{CO}_{3}$ & $\mathrm{BaCl}_{2}$ & $\mathrm{Zn}\left(\mathrm{NO}_{3}\right)_{2}$ & $\mathrm{Sr}\left(\mathrm{NO}_{3}\right)_{2}$ & $\begin{array}{l}\text { a. } \mathrm{Na}_{2} \mathrm{SO}_{4} \\
\text { b. } \mathrm{H}_{2} \mathrm{SO}_{4}\end{array}$ & $\mathrm{~Pb}\left(\mathrm{NO}_{3}\right)_{2}$ & $\mathrm{BaSO}_{4}$ \\
\hline \multicolumn{2}{|c|}{$\begin{array}{l}\text { W\&N production } \\
\text { record name }\end{array}$} & Code & \multicolumn{2}{|c|}{ Order of addition } & & \multicolumn{3}{|c|}{$\begin{array}{l}\text { Final pigment } \\
\text { formulation }\end{array}$} \\
\hline \multicolumn{2}{|c|}{ LEMON YELLOW } & LY1a & b & & & \multicolumn{3}{|c|}{$\mathrm{BaCrO}_{4}$} \\
\hline \multicolumn{2}{|c|}{ CITRON YELLOW } & CY1a & b & & & \multicolumn{3}{|c|}{$4 \mathrm{ZnCrO}{ }_{4} \cdot \mathrm{K}_{2} \mathrm{O} \cdot 3 \mathrm{H}_{2} \mathrm{O}$} \\
\hline \multicolumn{2}{|c|}{ STRONTIAN YELLOW } & SY1a & a & & & & \multicolumn{2}{|c|}{$\mathrm{SrCrO}_{4}$} \\
\hline \multicolumn{2}{|c|}{ LEMON CHROME } & L2a & $\mathbf{a}$ & a & & b & \multicolumn{2}{|c|}{$\mathrm{Pb}(\mathrm{Cr}, \mathrm{S}) \mathrm{O}_{4}+\mathrm{BaSO}_{4}$} \\
\hline
\end{tabular}


The core difference between W\&N's 19th century manufacture of barium, zinc and strontium chromate and lead chromate pigments is the degree of experimentation (Table 2). For the lead chromates, W\&N extensively tested sources for chromate, sulphate and lead as well as additives such as extenders and fillers [25]. In the manufacture of barium, zinc and strontium chromate pigments, experimentation was reduced to the choice of the chromate and metal ion source. No extenders or fillers were tested likely because these pigments present a lower tinting strength [27], see Tables 2, 3. Interestingly, Burnstock et al. did not find extenders in samples where these pigments were detected [6].

Table 2 shows that to produce W\&N's Lemon, Citron and Strontian Yellow, solutions of barium chloride, zinc nitrate and strontium nitrate were respectively added to a chromate solution $\left(\mathrm{CrO}_{4}{ }^{2-}\right)$. In the case of Citron Yellow, potassium carbonate was added as a buffer but may also act as an extra source of potassium. The resulting pigments present lighter yellow hues compared with pure lead chromate pigments [25], as presented in Table 3.

\section{Lemon Yellow (barium chromate, $\mathrm{BaCrO}_{4}$ )}

The 71 production records found for Lemon Yellow cover the period from 1838 to 1880 . These can be reduced to three main methods of synthesis. All manufacturing processes are depicted in Additional file 2: Table S2 .

The majority of the Lemon Yellow production records (64) pertain to the process coded LY1a, Table 2 and Eq. 1.

$$
\begin{gathered}
\mathrm{Cr}_{2} \mathrm{O}_{7}^{2-}(\mathrm{aq})+2 \mathrm{Ba}^{2+}(\mathrm{aq})+\mathrm{H}_{2} \mathrm{O} \\
\rightarrow 2 \mathrm{BaCrO}_{4}(\mathbf{s})+2 \mathrm{H}^{+}(\mathrm{aq})
\end{gathered}
$$

This is the only chromate pigment method of synthesis where $W \& N$ chose to use potassium dichromate alone without the addition of a buffer (in the form of a carbonate). This results in a very acidic final $\mathrm{pH}$, Table 3 . Of the three chromates studied here, barium chromate is the only one that precipitates regardless of the $\mathrm{pH}$, hence the absence of the buffer.

Four production records were found where a buffered chromate solution (potassium dichromate with potassium carbonate) was used. A single experiment with potassium chromate alone (this would result in a basic final $\mathrm{pH}$ ) was also conducted. Barium nitrate was also tried in two production records to substitute for barium chloride.

\section{Citron Yellow (zinc potassium chromate, $4 \mathrm{ZnCrO}{ }_{4} \cdot \mathrm{K}_{2} \mathrm{O} \cdot 3 \mathrm{H}_{2} \mathrm{O}$ )}

Twenty-six production records were found for zinc potassium chromate under the name Citron Yellow and Chromate of Zinc. These cover the period from 1834 to 1893 with the majority of the records dated in the 1850s. There are only three main methods of synthesis. All variations are presented in Additional file 2: Table S3.

Most of the Citron Yellow productions records (18) correspond to the process coded CY1a, Table 2 and Eq. 2.

$$
\begin{aligned}
& 4 \mathrm{CrO}_{4}^{2-}(\mathrm{aq})+2 \mathrm{~K}^{+}(\mathrm{aq})+4 \mathrm{Zn}^{2+}(\mathrm{aq})+4 \mathrm{H}_{2} \mathrm{O} \\
& \quad \rightarrow 4 \mathbf{Z n C r O}_{\mathbf{4}} \cdot \mathbf{K}_{\mathbf{2}} \mathbf{O} \cdot \mathbf{3} \mathbf{H}_{\mathbf{2}} \mathbf{O}(\mathbf{s})+2 \mathrm{H}^{+}(\mathrm{aq})
\end{aligned}
$$

For the manufacture of their Citron Yellow, W\&N primarily used potassium dichromate as the chromate source. Potassium carbonate was added to play three

\begin{tabular}{|c|c|c|c|c|c|c|}
\hline & Final $\mathrm{pH}^{\mathrm{a}}$ & $L^{*}$ & $a^{*}$ & $\mathbf{b}^{*}$ & $\%$ TS $^{b}$ & $\lambda_{\mathbb{I P}}(\mathrm{nm})$ \\
\hline \multirow{2}{*}{ LY1a } & $\approx 1$ & $89.9 \pm 3.2$ & $-7.7 \pm 0.5$ & $52.1 \pm 0.8$ & 92 & 450 \\
\hline & $\approx 5$ & $86.9 \pm 0.4$ & $5.1 \pm 0.4$ & $88.5 \pm 0.8$ & 65 & 510 \\
\hline & $\approx 8$ & $94.1 \pm 1.1$ & $-11.4 \pm 0.2$ & $55.2 \pm 0.2$ & 78 & $483(445$, sh) \\
\hline SY1a & & & & & & \\
\hline
\end{tabular}

Table 3 Reconstructions of W\&N's Lemon (LY1a), Citron (CY1a) and Strontian (SY1a) yellow pigments following their main synthetic pathways: final $\mathrm{pH}, \mathrm{L}^{*} \mathrm{a} * \mathrm{~b}^{*}$ colour coordinates, relative tinting strength $(\% \mathrm{TS})$ and inflection point $\left(\lambda_{\mathrm{lPr}}\right.$ $\mathrm{nm}$ ) of the reflectance spectra 
functions: to shift the dissociation reaction of dichromate into chromate, and to act as a buffer and an additional potassium source. This particular reaction results in a pigment formula different from the common chemical formula of yellow chromates, $\mathrm{MCrO}_{4}(\mathrm{M}=\mathrm{Pb}, \mathrm{Ba}$ and $\mathrm{Sr}$ ), since potassium ion $(\mathrm{K})$ and "hydroxo aqua" ions are present in the crystal structure together with the zinc ion (Zn), Eq. 2 [12]. For this particular formula to precipitate, the buffered chromate solution needs to be around $\mathrm{pH} 6$ (achieved by the addition of the potassium carbonate) when the zinc nitrate is added. Precipitation does not occur in acidic conditions. There are five production records where potassium dichromate was used with sodium carbonate. W\&N also experimented with zinc sulphate and zinc acetate as zinc sources. In addition, they performed a test with potassium dichromate and zinc sulphate but it is unlikely that this resulted in pigment precipitation, due to the low $\mathrm{pH}$ of the potassium dichromate solution.

\section{Strontian Yellow (strontium chromate, $\mathrm{SrCrO}_{4}$ )}

Few production records were found for Strontian Yellow: just six, all dated in the 1850s. There were three methods of synthesis, which are depicted in Additional file 2: Table S4. As noted above, the low number of production records suggests that $\mathrm{W} \& \mathrm{~N}$ was not producing and consequently not selling strontium chromate on a large scale.

The majority of the Strontian Yellow productions records (4) pertain to the process coded SY1a, Table 2 and Eq. 3.

$$
\mathrm{CrO}_{4}^{2-}(\mathrm{aq})+\mathrm{Sr}^{2+}(\mathrm{aq}) \rightarrow \mathrm{SrCrO}_{4}(\mathbf{s})
$$

In addition to the main synthetic pathway, there is one production record where the pathway is very similar to CY1 $a$, with the addition of potassium carbonate before and during pigment precipitation, and another record where potassium chromate is used alone. As observed for zinc potassium chromate, when potassium dichromate is used, a carbonate compound must be added to shift the dissociation reaction of dichromate into chromate, enabling the precipitation to occur at $\mathrm{pH}>6$. No other sources of strontium were tested.

\section{Analytical characterisation of the reconstructed pigments}

The pigment reconstructions were synthesised following selected production records representative of W\&N's main manufacturing processes (Table 2). Syntheses are detailed in the experimental section. As mentioned above, the reconstructed pigments were then characterised by colorimetry, FORS, XRD, $\mu$-Raman and $\mu$-FTIR spectroscopies (experimental conditions in the "Experimental" section).

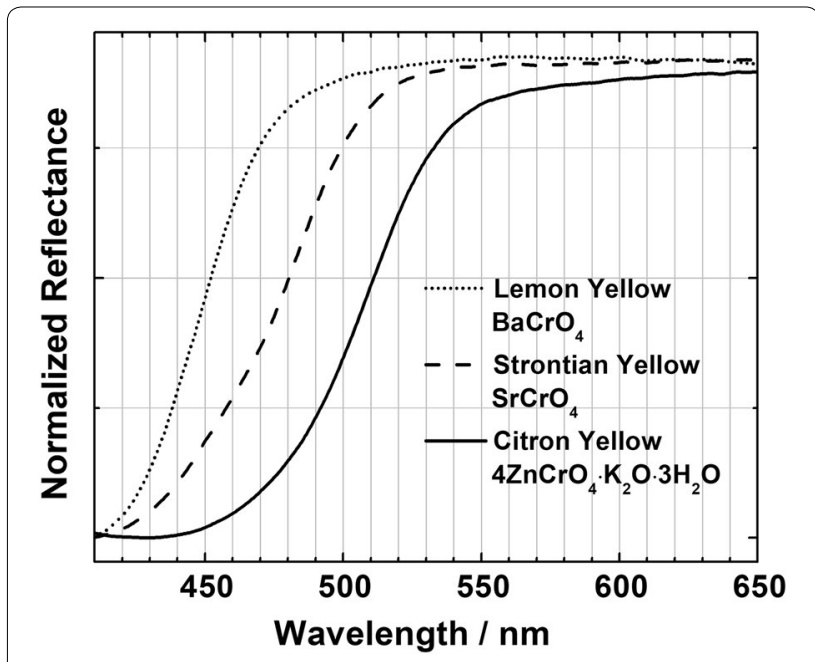

Fig. 3 Normalized FORS spectra of the pigment reconstructions for W\&N's Lemon $\left(\mathrm{BaCrO}_{4}\right)$, strontian $\left(\mathrm{SrCrO}_{4}\right)$ and Citron $\left(4 \mathrm{ZnCrO}_{4} \cdot \mathrm{K}_{2} \mathrm{O} \cdot 3 \mathrm{H}_{2} \mathrm{O}\right)$ Yellows

$\mathrm{L}^{*} \mathrm{a} * \mathrm{~b}$ * colour coordinates and the inflection point $\left(\lambda_{\mathrm{IP}}, \mathrm{nm}\right)$ of the reflectance spectra are shown in Table 3. Lemon and Strontian Yellows (b* around fifty) present a more greenish tone ( $\mathrm{a}^{*}$ negative) than Citron Yellow ( $\mathrm{a}^{*}$ positive). As shown in Fig. 3, their reflectance spectra present distinctive inflection points enabling their in situ identification by FORS. However, Citron Yellow presents the inflection point of the reflectance spectra closer to that observed for the lighter hues of lead chromate pigments [25].

The identification of these yellow chromate pigments is very straightforward by $\mu$-FTIR, $\mu$-Raman and XRD. Their distinctive infrared and Raman spectral fingerprints are shown in Fig. 4, and their diffraction patterns (identification cards from the International Centre for Diffraction Data, ICDD) are presented in Figs. 5 and 6.

The characteristic infrared and Raman bands of the pigments' chromophores are detailed in Table 4 and the spectral assignments were made in accordance to the literature $[12,13,22,28-30]$. As may be seen in Fig. 4 and Table 4, their infrared spectra present distinctive spectral profiles assigned to the $\mathrm{CrO}_{4}{ }^{2-}$ asymmetric stretching mode (between 1000 and $700 \mathrm{~cm}^{-1}$ ). On the other hand, their Raman spectra display differences in their main band assigned to the $\mathrm{CrO}_{4}{ }^{2-}$ symmetric stretching mode, which together with the $\mathrm{CrO}_{4}{ }^{2-}$ asymmetric stretching bands (in the region $850-950 \mathrm{~cm}^{-1}$ ) allows a complete differentiation between these pigments. This is particularly important when these pigments are found together as will be shown below. 


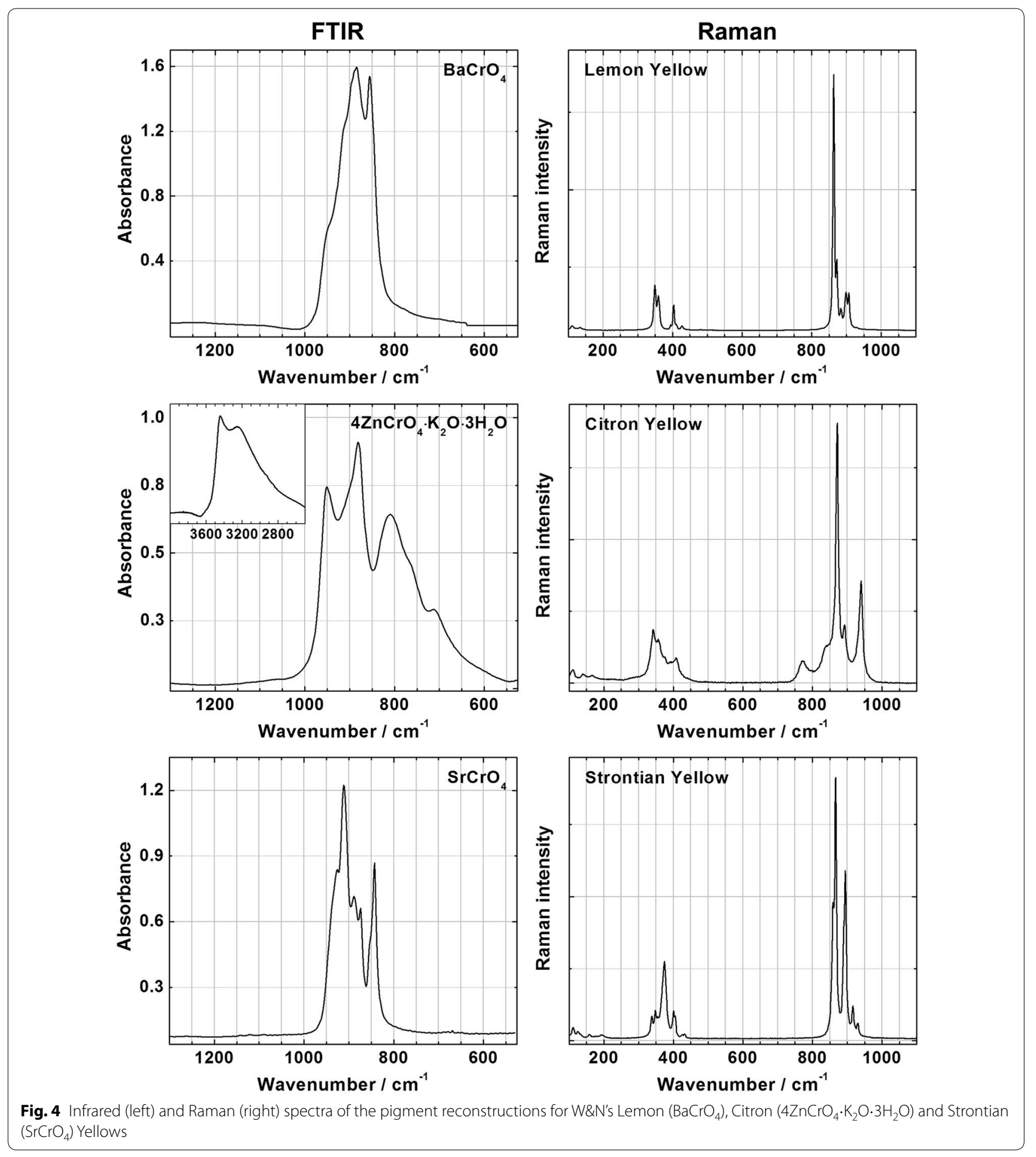

Comparison of the pigment reconstructions with paint samples from an historic W\&N oil paint tube and from late 19th-early 20th century oil paintings

A comparison was made with a late 19th century W\&N oil paint tube labelled "Lemon Yellow" (dated according to the data on the label; more details in the
"Experimental" section). The pigment in the tube is composed of barium chromate and the additive magnesium carbonate was also found, Fig. 6. Magnesium carbonate was only detected by $\mu$-FTIR, not by XRD, which means it is most probably in its amorphous form. As seen in Fig. 6, the infrared (between 1000 and $750 \mathrm{~cm}^{-1}$ ) and 

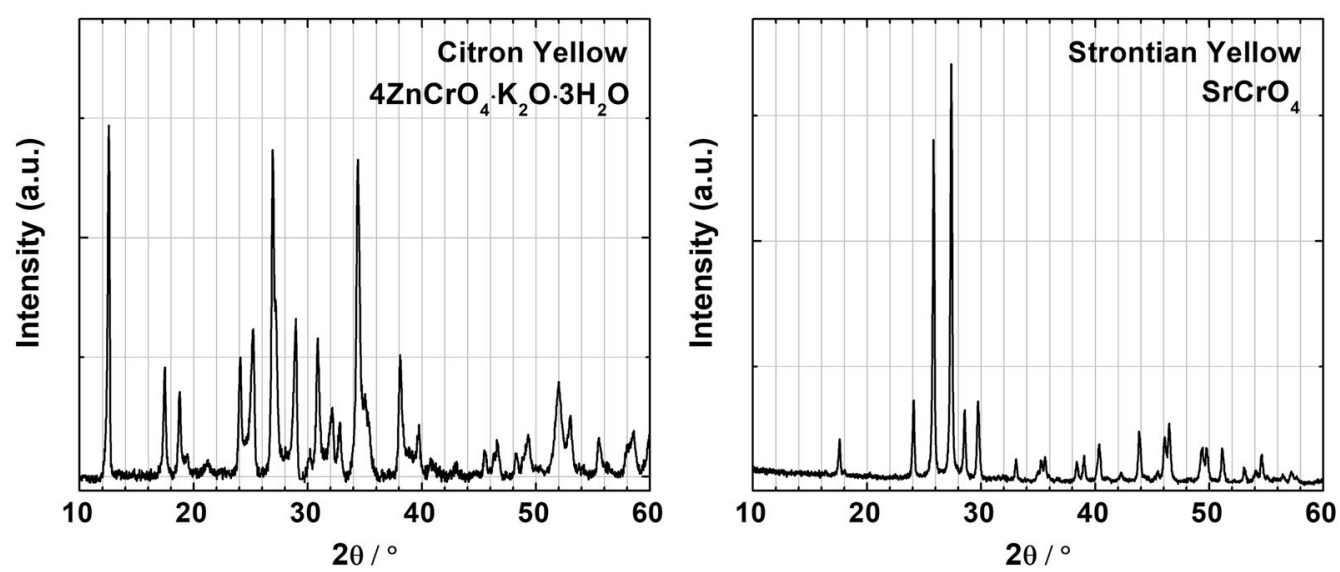

Fig. 5 Diffraction patterns of the pigment reconstructions for W\&N's Citron (matched with $4 \mathrm{ZnCrO}_{4} \cdot \mathrm{K}_{2} \mathrm{O} \cdot 3 \mathrm{H}_{2} \mathrm{O}$ ICDD card 00-008-0202) and Strontian (matched with $\mathrm{SrCrO}_{4}$ ICDD card 00-035-0743) Yellows

diffraction pattern of the pigment in the "Lemon Yellow" oil paint tube presents a very good match with the pigment reconstruction for W\&N's Lemon Yellow (LY1a, barium chromate). The presence of magnesium carbonate in the oil paint tube is very interesting. This material was not listed in any of the W\&N production records for manufacturing Lemon Yellow pigments, nor was it found in any of their 19th century production records for lead chromate pigments but it was detected in 19th century W\&N lead chromate oil paint tubes [25]. However magnesium carbonate does appear in some of W\&N's oil paint formulations under the term "spar" [25], as revealed by a search in the on-line W\&N Archive Database under the book code GR (entitled 'Oil Grinding at New Factory, various colours at different dates') [31]. It is possible that magnesium carbonate may be a good marker for W\&N's oil paints. Investigation into the oil paint formulations of other contemporary colourmen will be necessary to confirm this hypothesis.

Barium, zinc potassium and strontium chromates have been found in oil paintings by the Portuguese Naturalists Marques de Oliveira and Silva Porto, Fig. 1 and Additional file 1: Figure S1 [20]. Their identification has been primarily carried out by analysis of cross-sections from yellow colours using $\mu$-Raman, Additional file 3: Figures S5-S7.

Nonetheless, in the infrared spectrum of a $\mu$-sample from the yellow paint in the woman's scarf in Marques de Oliveira's painting $\dot{A}$ espera dos barcos (estudo) (Fig. 1 Top) it was possible to find the $\mathrm{CrO}_{4}{ }^{2-}$ asymmetric stretching fingerprint profile (between 1000 and $700 \mathrm{~cm}^{-1}$ ) of a pigment reconstruction for W\&N's Citron Yellow (CY1a, zinc potassium chromate), Fig. 7a. This pigment was found together with barium chromate and lead white, whose presence was confirmed by $\mu$-Raman, Fig. 7b and Additional file 3: Figure S5. In the same painting, the pigment zinc potassium chromate was found mixed with Prussian blue and lead white to produce the green colour in the sea.

Strontium chromate was also identified in the painting Entrada (Fig. 2) by the Portuguese Modernist Amadeo de Souza-Cardoso [21]. The infrared and $\mu$-Raman spectra of the yellow paint are presented in Fig. 8 showing a direct match with the $\mathrm{CrO}_{4}{ }^{2-}$ stretching fingerprint spectral profile of a pigment reconstruction for W\&N's Strontian Yellow (SY1a, strontium chromate). Despite this match, we believe that this strontium chromate was supplied by a manufacturer other than W\&N since we feel it was unlikely that W\&N was selling strontium chromate at the time this painting was executed in the beginning of the 20th century. Furthermore, strontium chromate was found together with lead white, strontium sulphate and gypsum, Fig. 8a. The presence of these extenders also supports our assumption that this paint was most probably supplied by another manufacturer but we cannot exclude the possibility that this particular mixture could have been prepared by Amadeo himself.

\section{Conclusions}

Access to the production records from W\&N's 19th century archive database made it possible to carry out a comprehensive study of their manufacturing processes for yellow chromate pigments based on barium $\left(\mathrm{BaCrO}_{4}\right)$, zinc $\left(4 \mathrm{ZnCrO}_{4} \cdot \mathrm{K}_{2} \mathrm{O} \cdot 3 \mathrm{H}_{2} \mathrm{O}\right)$ and strontium $\left(\mathrm{SrCrO}_{4}\right)$. One hundred and three production records were found for the manufacture of Lemon Yellow (barium chromate, $69 \%$ ), Citron Yellow (zinc potassium chromate, 25\%) and Strontian Yellow (strontium chromate, 6\%). The majority 

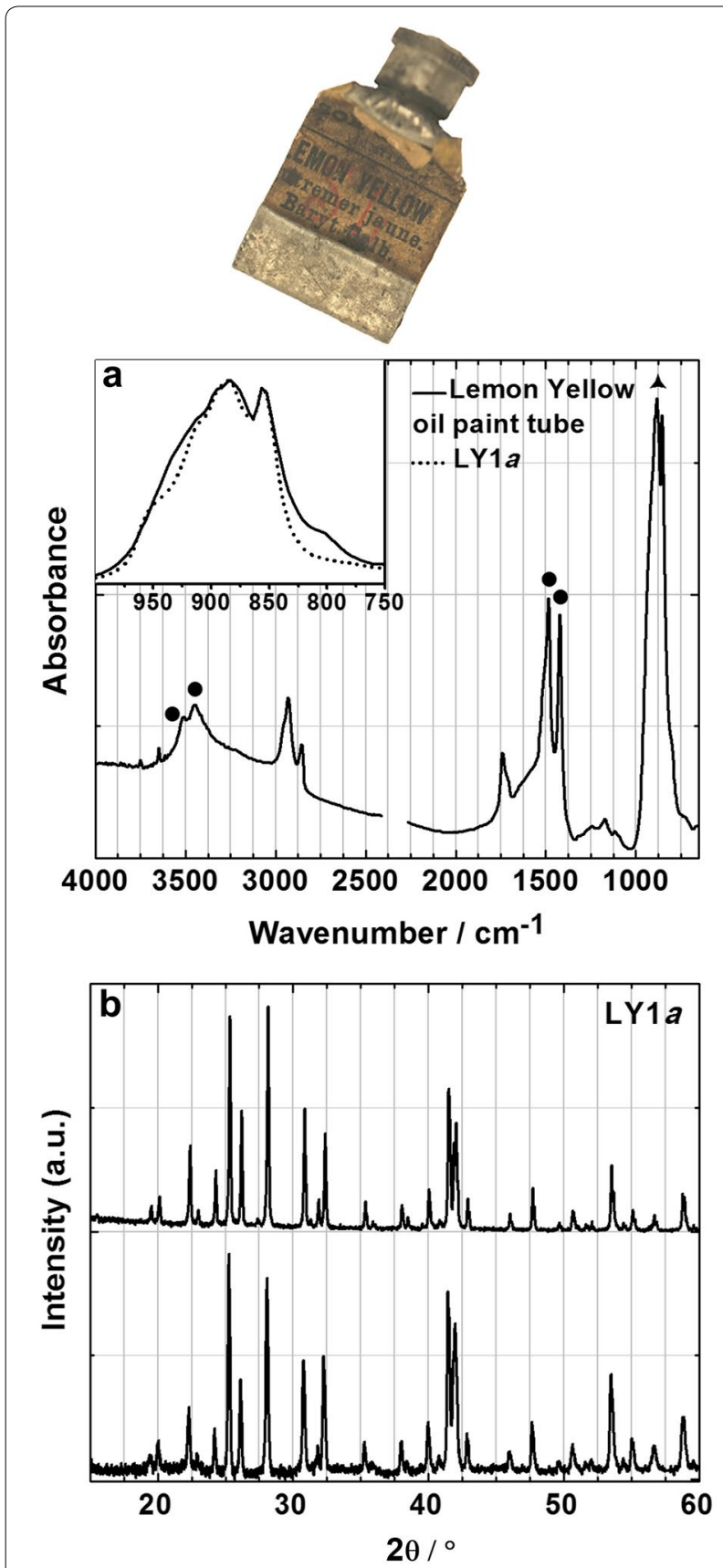

Fig. 6 a Infrared spectra (inset between 1000 and $750 \mathrm{~cm}^{-1}$ ) and b diffraction patterns (matched with $\mathrm{BaCrO}_{4}$ ICDD card 00-078-1401) of a late 19th century W\&N "Lemon Yellow" oil paint tube compared with a $\mathrm{LY} 1$ a pigment reconstruction; $(\boldsymbol{\Lambda}) \mathrm{BaCrO}_{4}(\mathbf{\bullet}) \mathrm{MgCO}_{3} \cdot \mathrm{H}_{2} \mathrm{O}$

covers the period between 1838 and 1871. Analysis of W\&N's production records indicates that one main synthetic pathway was found for each pigment. The $\mathrm{pH}$ was a key factor controlled by W\&N to achieve precipitation of zinc potassium and strontium chromate pigments.
There was no evidence that extenders were added during the synthesis of these pigments, whereas their production records for lead chromates do show the addition of extenders [25]. The lack of extenders for these pigments may infer that for W\&N, extenders were primarily present to adjust physical properties, tinting strength or hue, rather than functioning predominantly as a means to reduce the cost of materials. The relative tinting strength (TS) of these pigments is lower than pure lead chromate pigments. It was calculated in comparison to pure lead chromate $\left(\mathrm{PbCrO}_{4},\right)$ which was assigned a TS of $100 \%$. This resulted in a TS of $92 \%$ for barium, $78 \%$ for strontium and $65 \%$ for zinc potassium chromate pigments.

The low number of production records for strontium chromate indicates that W\&N was not selling a Strontian Yellow composed of strontium chromate on a large scale. As discussed above, evidence from their archive and their 1892 publication of colour compositions indicates that they rejected this pigment due to it being considered fugitive. This provides further evidence to support our conclusion that W\&N had a strong commitment to the durability of their products [25, 27].

The unique spectral fingerprints of the reconstructed pigments produced in accordance to W\&N's main manufacturing processes correlate very well with those detected in samples from a late 19th century W\&N "Lemon Yellow" oil paint tube and from late 19th and early 20th century Portuguese oil paintings. This validates their function as reference materials and contributes to a better understanding of the appearance and condition of these pigments when freshly produced. These reconstructed pigments are now available for further chemical studies to characterise and verify mechanisms of degradation and change.

\section{Experimental}

\section{Reagents}

All reagents and solvents were of analytical grade, and Millipore water was used.

\section{Pigment synthesis methods}

The pigment synthesis methods followed the main synthetic pathways depicted in Table 2. All pigments were thoroughly washed with cold water and diethyl ether, dried and then ground to a powder.

Barium chromate was prepared by adding $10 \mathrm{ml}$ of an aqueous solution of barium chloride $[5 \mathrm{~g}(0.02 \mathrm{~mol})$ of $\mathrm{BaCl}_{2}$ dissolved in $30 \mathrm{ml}$ of $\mathrm{H}_{2} \mathrm{O}$ ] to $100 \mathrm{ml}$ of boiling water where an aqueous solution of potassium dichromate $\left[1.3 \mathrm{~g}(0.004 \mathrm{~mol})\right.$ of $\mathrm{K}_{2} \mathrm{Cr}_{2} \mathrm{O}_{7}$ dissolved in $13 \mathrm{ml}$ of $\mathrm{H}_{2} \mathrm{O}$ ] was previously added. The solution where precipitation occurred was kept stirring for $10 \mathrm{~min}$ and left to settle for $1 \mathrm{~h}$. Yield $\approx 75 \%$. 
Table 4 Reconstructions of W\&N's Lemon (LY1a), Citron (CY1a) and Strontian (SY1a) yellow pigments: pigment composition, Raman and infrared characteristic bands [12, 13, 22, 28-30] (the main bands appear in italic)

\begin{tabular}{|c|c|c|c|c|c|c|}
\hline \multirow[t]{2}{*}{ Pigment composition } & \multicolumn{2}{|l|}{ Lemon yellow (LY1a) } & \multicolumn{2}{|l|}{ Citron yellow (CY1a) } & \multicolumn{2}{|c|}{ Strontian yellow (SY1a) } \\
\hline & \multicolumn{2}{|l|}{$\mathrm{BaCrO}_{4}$ orthorhombic } & \multicolumn{2}{|l|}{$4 \mathrm{ZnCrO}_{4} \cdot \mathrm{K}_{2} \mathrm{O} \cdot 3 \mathrm{H}_{2} \mathrm{O}$ monoclinic } & \multicolumn{2}{|l|}{$\mathrm{SrCrO}_{4}$ monoclinic } \\
\hline \multicolumn{7}{|l|}{ Infrared bands $\left(\mathrm{cm}^{-1}\right)$} \\
\hline $\mathrm{v}(\mathrm{OH})$ & - & & 3442 & & - & \\
\hline \multirow[t]{2}{*}{$\mathrm{V}_{\mathrm{as}}\left(\mathrm{CrO}_{4}^{2-}\right)$} & 885 & s & 881 & s & 911 & s \\
\hline & 855 & sh & 951,809 & sh & $888,874,843$ & sh \\
\hline \multicolumn{7}{|l|}{ Raman bands $\left(\mathrm{cm}^{-1}\right)$} \\
\hline$\delta\left(\mathrm{CrO}_{4}{ }^{2-}\right)$ & $349,360,403,427$ & $w-m$ & 342,408 & $w-m$ & $338,348,374,400$ & $w-m$ \\
\hline $\mathrm{V}_{\mathrm{s}}\left(\mathrm{CrO}_{4}{ }^{2-}\right)$ & 862 & s & 872 & s & 866 & s \\
\hline \multirow[t]{2}{*}{$\mathrm{V}_{\mathrm{as}}\left(\mathrm{CrO}_{4}{ }^{2-}\right)$} & $872,898,906$ & $w-m$ & 892 & sh & 894 & $\mathrm{~m}$ \\
\hline & & & 940 & $\mathrm{~m}$ & 916,930 & $w-n$ \\
\hline
\end{tabular}

$w-m$ weak to medium, $m$ medium, $s$ strong, sh shoulder
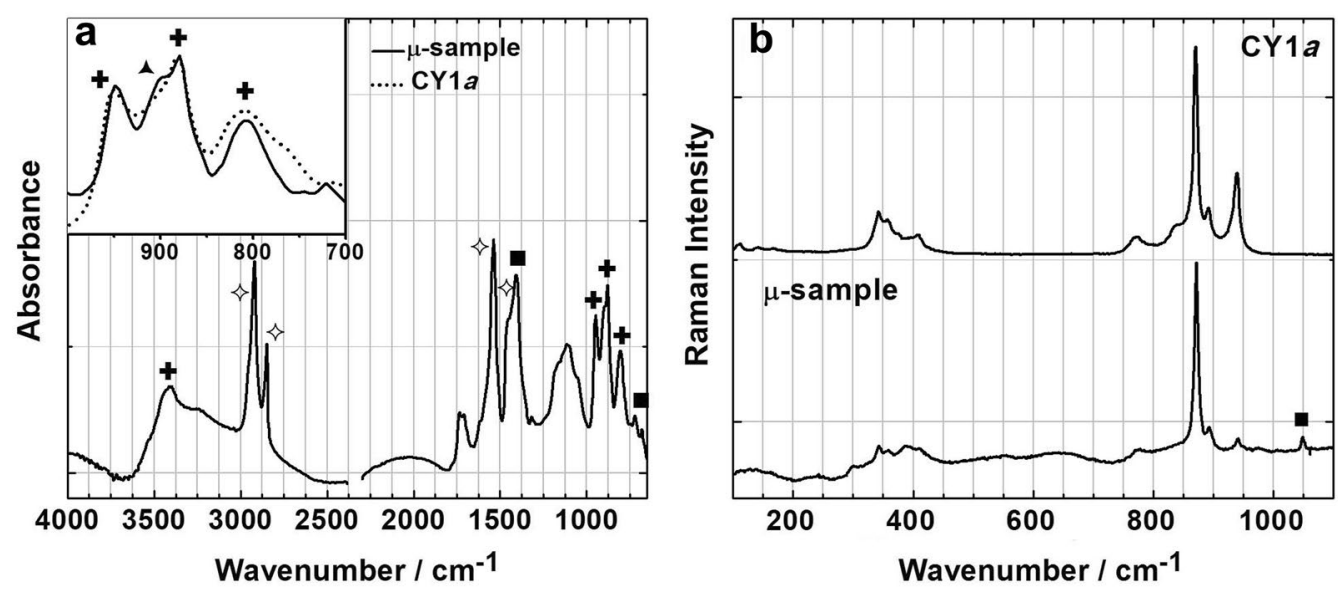

Fig. 7 a Infrared (inset between 1000 and $700 \mathrm{~cm}^{-1}$ ) and $\mathbf{b}$ Raman spectra of a yellow $\mu$-sample from Marques de Oliveira's painting $A$ espera dos barcos (estudo), 1891 (Fig. 1 top), compared with the spectra of a $\mathrm{CY}_{1}$ a pigment reconstruction; $(\mathbf{(}) 4 \mathrm{ZnCrO}_{4} \cdot \mathrm{K}_{2} \mathrm{O} \cdot 3 \mathrm{H}_{2} \mathrm{O},(\mathbf{\Delta}) \mathrm{BaCrO}_{4} ;(\diamond)$ zinc carboxylate, $2 \mathrm{PbCO}_{3} \cdot \mathrm{Pb}(\mathrm{OH})_{2}$

Zinc potassium chromate hydrate was synthesized by adding, dropwise, $50 \mathrm{ml}$ of an aqueous solution of zinc nitrate hexahydrate $\left[2.9 \mathrm{~g}(0.01 \mathrm{~mol})\right.$ of $\mathrm{Zn}\left(\mathrm{NO}_{2}\right)_{3} \cdot 6 \mathrm{H}_{2} \mathrm{O}$ dissolved in $50 \mathrm{ml}$ of $\mathrm{H}_{2} \mathrm{O}$ ] to an aqueous solution of potassium dichromate and potassium carbonate [2.9 $\mathrm{g}$ $(0.01 \mathrm{~mol})$ of $\mathrm{K}_{2} \mathrm{Cr}_{2} \mathrm{O}_{7}$ and $0.3 \mathrm{~g}(0.002 \mathrm{~mol})$ of $\left.\mathrm{K}_{2} \mathrm{CO}_{3}\right]$. After the addition of zinc nitrate, $0.05 \mathrm{~g}(0.0004 \mathrm{~mol})$ of $\mathrm{K}_{2} \mathrm{CO}_{3}$ was added. The solution where precipitation occurred was kept stirring for $15 \mathrm{~min}$. Yield $\approx 59 \%$.

Strontium chromate was produced by adding an aqueous solution of strontium nitrate $[1.1 \mathrm{~g}(0.005 \mathrm{~mol})$ of $\mathrm{Sr}\left(\mathrm{NO}_{3}\right)_{2}$ dissolved in $25 \mathrm{ml}$ of boiling $\mathrm{H}_{2} \mathrm{O}$ ] to an aqueous solution prepared by dissolving $0.75 \mathrm{~g}(0.0025 \mathrm{~mol})$ of $\mathrm{K}_{2} \mathrm{Cr}_{2} \mathrm{O}_{7}$ in $25 \mathrm{ml}$ of boiling $\mathrm{H}_{2} \mathrm{O}$ and then adding $\mathrm{Na}_{2} \mathrm{CO}_{3}$ until a neutral $\mathrm{pH}$ was reached. The solution where precipitation occurred was kept stirring for $10 \mathrm{~min}$ and left to settle until next day. Yield $\approx 69 \%$.

\section{Calculation of the tinting strength}

The relative tinting strength was calculated using the ASTM Standard Test Method D4838-88(2003). Poly(vinyl acetate) paints were prepared with the reconstructed pigments and barium sulphate, which was added until a maximum reflectance between 35 and $45 \%$ was obtained. A poly(vinyl acetate) paint of lead chromate and barium sulphate was used as the standard. The reflectance spectra were acquired in paint drawdowns applied with a thickness of $100 \mu \mathrm{m}$. The relative tinting strength calculated does not account for differences in hue and chroma. 

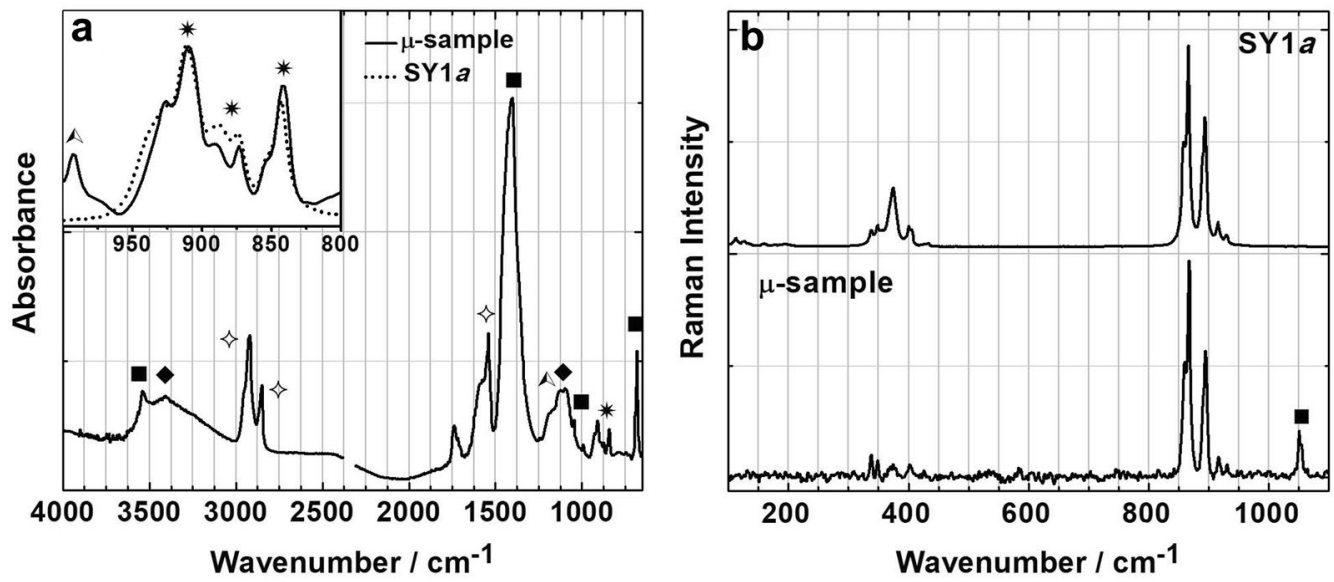

Fig. 8 a Infrared (inset between 1000 and $800 \mathrm{~cm}^{-1}$ ) and $\mathbf{b}$ Raman spectra of a yellow $\mu$-sample from Amadeo's painting Entrada, c. 1917 (Fig. 2), compared with the spectra of a SY1 a pigment reconstruction; ( $(*) \mathrm{SrCrO}_{4}$, $2 \mathrm{PbCO}_{3} \cdot \mathrm{Pb}(\mathrm{OH})_{2},(\mathbb{N}) \mathrm{SrSO}_{4}$ $\mathrm{CaSO}_{4} \cdot 2 \mathrm{H}_{2} \mathrm{O}$, (४) zinc carboxylate

\section{Samples}

Micro-sampling of the oil paintings was carried out using a micro-chisel from Ted Pella microtools under a Leica MZ16 stereomicroscope $(7.1 \times$ to $115 \times$ zoom range $)$, equipped with a Leica ICD digital camera and a fibreoptic light Leica system (Leica KI 1500 LCD).

The late 19th century W\&N Lemon Yellow oil paint tube was acquired on eBay and dated according to the appearance and data on the label. It contained enough paint for characterisation by XRD.

\section{Apparatus \\ Colorimetry}

For measuring colour, a portable spectrophotometer colorimetry Data Color International was used. Its measuring head's optical system uses diffuse illumination from a pulsed Xenon arc lamp over the $8 \mathrm{~mm}$-diameter measuring area, with $0^{\circ}$ viewing angle geometry. Colour coordinates were calculated defining the D65 illuminant and the $10^{\circ}$ observer. The reference source chosen was $C$ and calibration was performed with a white, bright standard plate $\left(\mathrm{L}^{*}=97.83 ; \mathrm{a}^{*}=0.52 ; \mathrm{b}^{*}=2.39\right)$ and a total black standard. Colour, as perceived by the human eye, may be represented in a three dimensional system. The colour data are presented in the CIE-Lab system. In the Lab cartesian system, $\mathrm{L}^{*}$, relative brightness, is represented by the $\mathrm{z}$-axis. Variations in relative brightness range from white $\left(L^{*}=100\right)$ to black $\left(L^{*}=0\right)$. The red \pm green $y$-axis plots $\mathrm{a}^{*}$, ranging from negative values (green) to positive (red). The yellow \pm blue $x$-axis reports $b^{*}$, going from negative (blue) to positive numbers (yellow). The $\left(\mathrm{a}^{*}, \mathrm{~b}^{*}\right)$ pair represents the hue of the object.

\section{FORS}

Reflectance spectra were acquired with Ocean Optics equipment composed by a single-beam dispersive fibre optic spectrometer (model MAYA 2000 PRO) equipped with 2048 linear silicon CCD array detector (Hamamatsu). The MAYA 2000 PRO has a spectral response from 200 to $1050 \mathrm{~nm}$. The illumination is an Ocean Optics HL-2000-HP with $20 \mathrm{~W}$ halogen light source in a single optical path covering the 360-2400 nm range. Spectra were obtained with an integration time of $8 \mathrm{~ms}$ and 15 scans to average. The measuring head, in a $45^{\circ} / 45^{\circ}$ (illumination/acquisition angles) configuration, gives a diameter of analysis of about $2 \mathrm{~mm}$. As reference a Spectralon ${ }^{\circledR}$ standard was used. The wavelength of the inflection point was obtained from the reflectance spectra.

\section{$X R D$}

X-ray diffractograms were acquired with a PANalytical X'Pert PRO diffractometer equipped with a X'Celerator detector and using $\mathrm{CuK} \alpha$ radiation in the $10<2 \theta<80$ range with a step size of $0.02^{\circ}$ in Bragg-Brentano configuration. XRD was performed at CENIMAT/i3N-Centro de Investigação de Materiais/Instituto de Nanoestruturas, Nanomodelação e Nanofabricação of the Universidade NOVA de Lisboa.

\section{Micro-Raman}

Raman microscopy was carried out using a Labram 300 Jobin-Yvon spectrometer, equipped with a HeNe laser $17 \mathrm{~mW}$ operating at $632.8 \mathrm{~nm}$. Spectra were recorded as an extended scan. The laser beam was focused with 
$50 \times$ Olympus objective lens. The laser power at the surface of the samples was varied with the aid of a set of neutral density filters. All samples were analysed using $15 \mathrm{~s}$ laser exposure time for five scans.

\section{Micro-FTIR}

Infrared analyses were carried out with a Nicolet Nexus spectrophotometer coupled to a Continu $\mu \mathrm{m}$ microscope $(15 \times$ Objective $)$ with a MCT-A detector cooled by liquid nitrogen. The pigments were prepared as $\mathrm{KBr}$ pellets, and spectra were collected in transmission mode, with a resolution of $4 \mathrm{~cm}^{-1}$ and 64 scans. For the micro-samples from oil paints and paintings, spectra were obtained in transmission mode, $4000-650 \mathrm{~cm}^{-1}$, with a resolution of $4 \mathrm{~cm}^{-1}$ and 128 scans, using a Thermo diamond anvil compression cell. The spectra are shown here as acquired, without corrections or any further manipulations, except for the removal of the $\mathrm{CO}_{2}$ absorption at ca. $2300-2400 \mathrm{~cm}^{-1}$.

\section{Additional files}

Additional file 1. Two other paintings by Silva Porto.

Additional file 2. Full description of W\&N 19th century manufacturing processes for Lemon (barium chromate), Citron (zinc potassium chromate) and Strontian (strontium chromate) Yellows.

Additional file 3. $\mu$-Raman characterisation of yellow $\mu$-samples from case studies.

\section{Authors' contributions}

VO carried out the investigation on the yellow chromate pigments and drafted the manuscript. MC carried out the analysis of the oil paintings by Silva Porto and Marques de Oliveira. JP acquired the XRD data. MV, LC and MJM supervised the investigation and revised the manuscript. All authors read and approved the final manuscript

\section{Author details}

1 Department of Conservation and Restoration and LAQV-REQUIMTE, Faculty of Sciences and Technology, Universidade NOVA de Lisboa, 2829-516 Monte da Caparica, Portugal. ${ }^{2}$ CENIMAT/I3N, Material Science Department, Faculty of Sciences and Technology, Universidade NOVA de Lisboa, 2829-516 Monte da Caparica, Portugal.

\section{Acknowledgements}

The authors acknowledge the Portuguese Science Foundation (FCT) for Ph.D Grants SFRH/BD/74574/2010 (Vanessa Otero), SFRH/BD/70093/2010 (Marta F. Campos) and project PTDC/EAT-EAT/113612/2009. We also thank the LAQVREQUIMTE for supporting project UID/QUI/50006/2013 and CENIMAT/i3N for UID/CTM/50025/2013. The authors are grateful to ColArt Fine Art \& Graphics Ltd. for access to the W\&N archive, in particular Emma Pearce and lan Garrett for making the archive database project possible. The W\&N 19th century Archive Database project was initially funded by the Netherlands Institute for Scientific Research (NWO) as part of the De Mayerne Programme, then in the UK, by a Resource Enhancement Grant from the Arts and Humanities Research Council (AHRC). We would like to thank Cristina Montagner for her contribution to the analyses of Amadeo de Souza-Cardoso's paintings and we are also thankful to the team members of the Modern Art Centre of the Calouste Gulbenkian Foundation, the National Museum of Contemporary Art-Museu do Chiado and the House-Museum Dr. Anastácio Gonçalves.
Competing interests

The authors declare that they have no competing interests.

Availability of data and materials

Not applicable.

Consent for publication

Not applicable.

Ethics approval and consent to participate

Not applicable.

\section{Funding}

The research was funded by the Portuguese Science Foundation (FCT) through the Ph.D grants SFRH/BD/74574/2010 (Vanessa Otero) and SFRH/BD/70093/2010 (Marta F. Campos), as well as the projects PTDC/ EAT-EAT/113612/2009, UID/QUI/50006/2013 (LAQV-REQUIMTE) and UID/ CTM/50025/2013 (CENIMAT/i3N). FEDER funds through the COMPETE 2020 Programme under the project numbers POCI-01-0145-FEDER-007265 and POCI-01-0145-FEDER-007688 are also acknowledged.

\section{Publisher's Note}

Springer Nature remains neutral with regard to jurisdictional claims in published maps and institutional affiliations.

Received: 19 August 2017 Accepted: 16 October 2017

Published online: 14 November 2017

\section{References}

1. Vauquelin LN. Mémoire sur la meilleure méthode pour décomposer le chrômate de fer, obtenir l'oxide de chrôme, préparer l'acide chrômique, et sur quelques combinaisons de ce dernier. Ann Chim. 1809;70:70-94.

2. Kühn H, Curran M. Chrome yellow and other chromate pigments. In: Feller RL, editor. Artists' pigments: a handbook of their history and characteristics, vol. 1. 1st ed. Cambridge: Cambridge University Press and National Gallery of Art; 1986. p. 201-7.

3. Bomford D, Kirby J, Leighton J, Roy A. Art in the making, impressionism. London: National Gallery Publications Ltd.; 1990. p. 32-43, 51-72.

4. Kirby J, Stonor K, Roy A, Burnstock A, Grout R, White R. Seurat's painting practice: theory, development and technology. Natl Gallery Tech Bull. 2003;24:4-37

5. Carlyle L. The artist's assistant: oil painting instruction manuals and handbooks in Britain, 1800-1900, with reference to selected eighteenthcentury sources. London: Archetype Publications; 2001. p. 521-526, 536.

6. Burnstock AR, Jones CG, Cressey G. Characterisation of artists' chromiumbased yellow pigments. Z für Kunsttechnol Konserv. 2003;17(74):74-84.

7. Krieg S. Anticorrosive pigments. In: Buxbaum G, Pfaff G, editors. Industrial inorganic pigments. 3rd ed. Weinheim: Wiley-VCH Verlag GmbH \& Co KGaA; 2005. p. 212-4.

8. Chang R. Química. 5th ed. Portugal: McGraw-Hill; 1994. p. 757-9.

9. Liang J, Peng Q, Wang X, Zheng X, Wang R, Qiu X, Nan C, Li Y. Chromate nanorods/nanobelts: general synthesis, characterization, and properties. Inorg Chem. 2005:44:9405-15.

10. Lide DR, editor. CRC handbook of chemistry and physics. 87th ed. USA: CRC Press; 2006. p. 8-118.

11. Cameo. http://cameo.mfa.org/wiki/Main_Page. 2016. Accessed 29 Feb 2016

12. Simonsen KP, Christiansen MB, Vinum MG, Sanyova J, Bendix J. Single crystal X-ray structure of the artists' pigment zinc yellow. J Mol Struct. 2017;1141(5):322-7.

13. Alía JM, Edwards HGM, Fernández A, Prieto M. Fourier transform Raman spectroscopic study of $\mathrm{Ba}\left(\mathrm{SO}_{4}\right)_{x}\left(\mathrm{CrO}_{4}\right)_{1-x}$ solid solution. J Raman Spectrosc. 1999;30:105-14.

14. Eastaugh N, Walsh V, Chaplin T, Siddall R. The pigment compendium, a dictionary of historical pigments. 1st ed. Oxford: Elsevier ButterworthHeinemann; 2004. p. 36, 355, 409. 
15. Monico L, Janssens $K$, Miliani $C$, Brunetti BG, Vagnini M, Vanmeert $F$, Falkenberg G, Abakumov A, Lu Y, Tian H, Verbeeck J, Radepont M, Cotte M, Hendriks E, Geldof M, Loeff L, Salvant J, Menu M. Degradation process of lead chromate in paintings by Vincent van Gogh studied by means of spectromicroscopic methods. 3. Synthesis, characterization, and detection of different crystal forms of the chrome yellow pigment. Anal Chem. 2013;85:851-9.

16. Tan H, Tian H, Verbeeck J, Monico L, Janssens K, Tendeloo G. Nanoscale investigation of the degradation mechanism of a historical chrome yellow paint by quantitative electron energy loss spectroscopy mapping of chromium species. Angew Chem Int Ed. 2013;52:11360-3.

17. Casadio F, Fiedler I, Gray KA, Warta R. Deterioration of zinc potassium chromate pigments: elucidation the effects of paint composition and environmental conditions on chromatic alteration. In: Bridgland J, editor. Preprints of the ICOM-CC 15th Triennial Meeting, New Delhi, Allied Publishers; 2008, p. 572-80.

18. Casadio F, Xie S, Rukes SC, Myers B, Gray KA, Warta R, Fiedler I. Electron energy loss spectroscopy elucidates the elusive darkening of zinc potassium chromate in Georges Seurat's A Sunday on La Grande Jatte-1884 Anal Bioanal Chem. 2011;399:2909-20.

19. Zanella L, Casadio F, Gray KA, Warta R, Ma Q, Gaillard J. The darkening of zinc yellow: XANES speciation of chromium in artist's paints after light and chemical exposures. pl Anal At Spectrom. 2011;26:1090-7.

20. Campos MF. Materials and techniques of the Portuguese Naturalism: the cases of Silva Porto and Marques de Oliveira. PhD dissertation. Department of Conservation and Restoration of Universidade NOVA de Lisboa. forthcoming.

21. Montagner $\mathrm{C}$. The brushstroke and materials of Amadeo de Souza-Cardoso combined in an authentication tool. PhD dissertation. Department of Conservation and Restoration of Universidade NOVA de Lisboa. http:// hdl.handle.net/10362/14777.
22. Correia AM, Clark RJH, Ribeiro MIM, Duarte MLTS. Pigment study by Raman microscopy of 23 paintings by the Portuguese artist Henrique Pousão (1859-1884). J Raman Spectrosc. 2007;38:1390-405.

23. Carlyle L, Alves PC, Otero V, Melo MJ, Vilarigues M. A question of scale \& terminology, extrapolating from past practices in commercial manufacture to current laboratory experience: the Winsor \& Newton 19th century artists' materials archive database. In: Bridgland J, et al. editor. ICOM-CC 16th Triennial Conference Preprints, Lisbon, 2011, paper 0102.

24. Otero V, Carlyle L, Vilarigues M, Melo MJ. Chrome yellow in nineteenth century art: historical reconstructions of an artists' pigment. RSC Adv. 2013;2(5):1798-805

25. Otero V, Pinto JV, Carlyle L, Vilarigues M, Cotte M, Melo MJ. Nineteenth century chrome yellow and chrome deep from Winsor \& Newton ${ }^{\text {TM }}$. Stud Conserv. 2017;62(3):123-49.

26. Vibert JG. La Science de la Peinture. Paris: Paul Ollendorff; 1891. p. 98, 285.

27. Otero V, Vilarigues M, Carlyle L, Melo MJ. Winsor \& Newton's nineteenth century manufacture of yellow chromate-based pigments. In: Eyb-Green $\mathrm{S}$, et al., editors. Sources in art technology: back to basics. London: Archetype Publications; 2016. p. 149-50.

28. Hummel DO. Atlas of plastics additives. Analysis by spectrometric methods. Berlin: Springer-Verlag; 2002.

29. Stoilova D, Georgiev M, Marinova D. Infrared study of the vibrational behavior of $\mathrm{CrO}_{4}{ }^{2-}$ guest ions matrix-isolated in metal (II) sulfates (Me $=\mathrm{Ca}$, Sr, Ba, Pb). J Mol Struct. 2005;738:211-5.

30. Nakamoto K. Infrared and Raman spectra of inorganic and coordination compounds, theory and applications in inorganic chemistry. 6th ed. Hoboken: Wiley-Interscience; 2009.

31. On-line W\&N Archive Database, book code GR. http://webapps.fitzmuseum.cam.ac.uk/wn/search.php?s_arg=GR\&pid=sSearch\&opt\%5B\%5D= source_book\&cnt=25. Accessed 03 Aug 2017.

\section{Submit your manuscript to a SpringerOpen ${ }^{\circ}$ journal and benefit from:}

- Convenient online submission

- Rigorous peer review

- Open access: articles freely available online

- High visibility within the field

- Retaining the copyright to your article

Submit your next manuscript at $\$$ springeropen.com 